\title{
A SUPPLY CHAIN RISK EVALUATION METHOD BASED ON FUZZY TOPSIS
}

\author{
C. SUN ${ }^{1}$, Y. XIANG ${ }^{1}$, S. JIANG ${ }^{2}$ \& Q. CHE ${ }^{1}$ \\ ${ }^{1}$ School of Management, Harbin Institute of Technology, China. \\ ${ }^{2}$ Faculty of Infrastructure Engineering, Dalian University of Technology, China.
}

\begin{abstract}
A supply chain is a value-added chain and supply chain management (SCM) benefits enterprises through optimizing their internal business processes, lowering logistics costs, improving customer satisfaction, and more. While enhancing competitive ability and evading the risks of traditional management methods, SCM also carries its own risks. Initially, this paper studies major risk factors of the supply chain by analyzing its operating mechanism, essential characteristics, and results of previous research. Later, based on these risk factors, a supply chain risk evaluation index is presented based on the principle of comprehensive, rational, and systematic thinking. Finally, a method for evaluating supply chain risk is proposed based on Fuzzy TOPSIS (Fuzzy Technique for Order Preference by Similarity to an Ideal Solution - F-TOPSIS), and its validity is demonstrated in a case study. The research contribution of this paper can boost the practical application and theoretical development of supply chain risk management.
\end{abstract}

Keywords: Fuzzy TOPSIS, risk evaluation, supply chain.

\section{INTRODUCTION}

The development of the knowledge economy, the advances of science and technology, and the accelerated process of global economic integration create a highly complex environment for enterprises today; at the same time, competition between enterprises is increasing. In this new environment, supply chain management (SCM) has received much attention, because it uses external resources to enable enterprises to rapidly react to market demand. The Global Supply Chain Forum defines SCM as 'the integration of key business processes from end-user through original suppliers that provides products, services, and information that add value for customers and other stakeholders' [1]. The emergence of SCM drastically changes traditional management theories, methods, and thoughts, and leads a new trend in corporate management.

Due to the characteristics of the supply chain and its important role, there is wide and deep research on theoretical models and their application. For example, Min and Zhou [2] studied past supply chain modeling efforts, and have described the key challenges, opportunities, and future trends of the supply chain. They have also provided some guidance on how to develop and implement a supply chain successfully. Cao and Lin [3] have presented a closed-loop supply chain recovery model with the application of game theory, analyzing optimal pricing decisions and profits for all enterprise members in a decentralized structure. They too provided some useful suggestions for manufacturers, retailers, and third-party recyclers for improving their profits and performance. In promoting the better application of SCM, Askarany et al. [4] concluded, from a large questionnaire study, that the techniques of activity-based costing (ABC) could improve SCM and its performance in organizations. In fact, many internationally well-known enterprises such as IBM, Cisco, Dell, Coca Cola, Wal-Mart, and Toyota have achieved great success by using the supply chain approach. A benchmarking study conducted by the Pittigilo, Rabin, Todd \& McGrath (PRTM) consulting company reported that SCM affords leading companies a 40-50\% advantage in the cash-to-cash cycle, a $44 \%$ higher value added per employee, a 3-7\% reduction in total logistics costs as a percentage of revenue, a 50\% lower cost of ownership of materials, and a 30-50\% improvement in meeting commitment dates [5]. 
However, despite many successful implementations of supply chain technology, some enterprises have faced huge economic losses after improper implementation. For example, a fire broke out at a semiconductor factory in New Mexico, USA; because of Ericsson's - Europe's largest electronics company at the time - supply chain partnership with the factory, Ericsson's European division reported a loss of $\$ 1.68$ billion, a 3\% loss of market share, and an enterprise operating loss of $\$ 167$ million [6]. On March 11, 2011, an earthquake of magnitude 9.0 rocked the main island of Honshu, Japan, and many electronics and automotive companies both inside and outside Japan suffered huge losses from this earthquake due to the disruption of global manufacturing supply chains; for example, Honda lost \$558 million, HP lost \$700 million, and Toshiba lost \$2,900 million [7].

These instances are too numerous to list. It is therefore necessary for managers to strengthen their understanding of supply chain risk and to implement corresponding risk management. Many researchers have studied the problems of risk identification in the supply chain, strategies to avoid these risks, and the bullwhip effect. They have put forward many valuable methods. For example, Ghadge et al. [8] and Colicchia and Strozzi [9] summarized supply chain risk management (SCRM) by employing a systematic literature review and presenting some future research directions for SCRM, such as behavioral perceptions in risk management, risk mitigation through collaboration contracts, risk propagation, and recovery planning, modeling supply chains by considering robustness and resilience. Based on a description of supply chain risk analysis, Jukka et al. [10] put forward two kinds of supply chain risk analysis tools: internal auditing and computer-aided causal analysis. Despite these advances, based on an exploratory quantitative survey, Jüttner [11] concluded that most companies believe that the understanding of vulnerability of their supply chains and the concept of SCRM are still in their infancy.

Therefore, from a deep analysis of operating mechanisms, essential characteristics, and previous research results, this paper highlights the main risk factors present when a company applies the SCM method. Later, a supply chain risk evaluation index is established, and an evaluation method based on Fuzzy TOPSIS (F-TOPSIS) is proposed. Finally, with the help of a case study, its validity is demonstrated.

\section{RESEARCH METHODOLOGY}

The adoption of a research methodology should be based on the research content. There are two main aspects to the study in this paper: the establishment of a supply chain risk evaluation index and the selection of a supply chain risk evaluation method. For the first, considering the rationality and systematic nature of the evaluation index, the literature review method is adopted. For the second, taking into account its ease of use and suitability, the F-TOPSIS is adopted.

TOPSIS, which is similar to the Simple Additive Weighting (SAW) method [12], is a sorting method that is most effective at solving multi-objective decision-making problems. TOPSIS has two kinds of solutions: the ideal solution (recorded as $v^{*}$ ) and the negative ideal solution (recorded as $v^{0}$ ). The ideal solution is the best scheme for resolving a decision-making problem, and the negative ideal solution is the worst. When comparing schemes with $v^{*}$ and $v^{0}$, the scheme which is nearest to $v^{*}$ and furthest from $v^{0}$ is the best scheme [13]. In practice, most of the evaluation index comprises qualitative indicators, so the fuzzy concept is introduced into TOPSIS, which then becomes F-TOPSIS.

The basic steps of F-TOPSIS are as follows [13,14]:

1. Organize the experts and evaluate each scheme. For one evaluation problem with $\mathrm{m}$ schemes and $\mathrm{n}$ indexes, a fuzzy decision-making matrix $D=\left(d_{i j}\right)_{\mathrm{M} \times \mathrm{N}}$ is obtained, where $d_{i j}$ denotes the fuzzy evaluation value of index $j$ in scheme $i$.

2. Calculate the weight of each index, where $W=\left(w_{1}, w_{2}, \ldots, w_{n}\right)$, using the defuzzification method for the calculation of matrix $D^{\prime}=\left(d^{\prime}{ }_{i j}\right)_{\mathrm{M} \times \mathrm{N}}$, where $d^{\prime}{ }_{i j}$ is the value after defuzzification of $d_{i j}$; 
then, through weighting and standardized processing a standardized decision matrix $V=\left(v_{i j}\right)_{\mathrm{M} \times \mathrm{N}}$ $=\left(w_{j} d^{\prime}{ }_{i j}\right)_{\mathrm{M} \times \mathrm{N}}$ is obtained.

3. Confirm the ideal solution $v^{*}$ and the negative ideal solution $v^{0}$ of the evaluation problem, as in eqn (1):

$$
v^{*}=\left\{v_{1}^{*}, v_{2}^{*}, \ldots, v_{n}^{*}\right\} ; v^{o}=\left\{v_{1}^{0}, v_{2}^{0}, \ldots, v_{n}^{0}\right\}
$$

where

$$
v_{j}^{*}=\left\{\begin{array}{l}
\max _{i} V_{i j}, j \hat{I} J_{1} \\
\min _{i} V_{i j}, j \hat{I} J_{2}
\end{array} \text { and } v_{j}^{0}=\left\{\begin{array}{l}
\min _{i} V_{i j}, j \hat{I} J_{1} \\
\max _{i} V_{i j}, j \hat{I} J_{2}
\end{array}\right.\right.
$$

$J_{1}$ and $J_{2}$ are the sets of benefit criteria and cost criteria, respectively.

4. Calculate the distance of each scheme from the ideal solution and the negative ideal solution: $S_{i}^{*}$ and $\mathrm{S}_{\mathrm{i}}^{0}$, as in eqns (2) and (3):

$$
\begin{aligned}
& \mathrm{S}_{\mathrm{i}}^{*}=\sqrt{\sum_{\mathrm{j}=1}^{\mathrm{n}}\left(\mathrm{v}_{\mathrm{ij}}-\mathrm{v}_{\mathrm{j}}^{*}\right)^{2}} \quad(i=1,2, \ldots, m) \\
& \mathrm{S}_{\mathrm{i}}^{0}=\sqrt{\sum_{\mathrm{j}=1}^{\mathrm{n}}\left(\mathrm{v}_{\mathrm{ij}}-\mathrm{v}_{\mathrm{j}}^{0}\right)^{2}} \quad(i=1,2, \ldots, m)
\end{aligned}
$$

5. Calculate the degree of closeness $\mathrm{S}_{\mathrm{i}}$ between each scheme and the ideal scheme, as in eqn (4):

$$
\mathrm{S}_{\mathrm{i}}=\frac{\mathrm{S}_{\mathrm{i}}^{0}}{\mathrm{~S}_{\mathrm{i}}^{*}+\mathrm{S}_{\mathrm{i}}^{0}}
$$

6. The value of $S_{\mathrm{i}}$ varies from 0 to 1 . Closer to 1 means a better scheme and closer to 0 means a worse scheme.

\section{ANALYSIS OF RISK FACTORS OF THE SUPPLY CHAIN}

\subsection{Operating mechanism and essential characteristics of the supply chain}

According to the common definition of supply chain, it is not only related to the work processes of one enterprise, but also to its suppliers, manufacturers, retailers, and other agents related to the

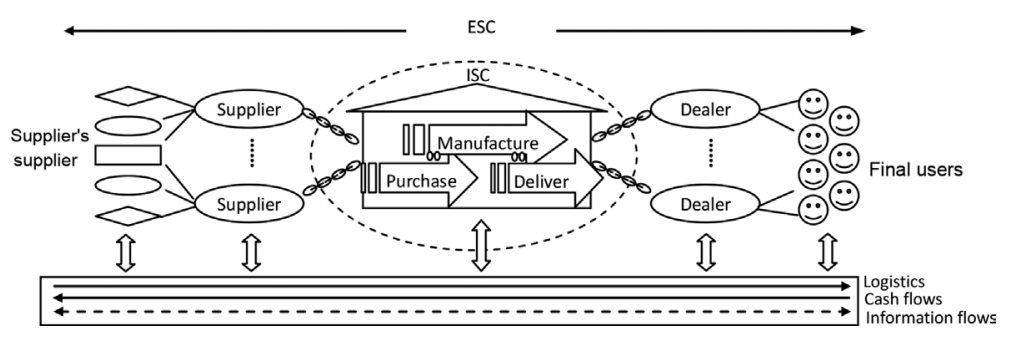

Figure 1: The structural model of the supply chain. 
enterprise. Therefore, some scholars have split the supply chain into an internal and an external supply chain [15]. The internal supply chain (ISC) is the supply and demand network consisting of procurement, manufacturing, warehousing, sales, and other departments in the enterprise. The external supply chain (ESC) contains all enterprises involved in the process of transforming raw materials into products delivered to final consumers. This operating mechanism is presented in Fig. 1.

SCM is very complicated and involves eight major business processes: customer relationship management (CRM), customer service management, demand management, order performance, processing flow management, supplier relationship management, product development and commercialization, and returns management [16]. Therefore, the supply chain can be regarded as a cross-organizational management and coordination model with these essential characteristics:

1. Requirement for unified management: Although SCM requires the coordination of all participating companies, they are all independent economic entities and have their own independent organizations, making it difficult to establish a unified regulation mechanism.

2. Dynamics of symbiosis between enterprises: The product market is changing, and customer demand is diverse. This requires that enterprises are flexible, rapidly react to market variations, and set up a supply chain quickly. For most supply chains, the cooperation among enterprises is not stable, it is fundamental to consider the fluidity of cooperation in the supply chain.

3. Integration of a variety of enabling technologies: The supply chain is a cross-enterprise management mode, which needs a lot of related technical support including CRM, Computer Integrated Manufacturing Systems (CIMS), Enterprise Resource Planning (ERP), the internet, e-commerce, and virtual and simulation technology. The effective integration of these technologies enables the goal of the supply chain to be realized.

4. Bullwhip effect in the process of information transfer: The bullwhip effect is also called the demand amplification effect. Because of it, upstream suppliers often have higher inventory levels than downstream suppliers [17].

5. Maximization of both overall and individual companies' interests in the supply chain: The maximization of profits is not only each company's goal, but it is the foundation of an enterprise's development. The supply chain pursues a win-win situation between enterprises, and realizes the best interests of each enterprise by using performance evaluation and an incentive mechanism, providing that it does not negatively affect the interests of the whole supply chain.

\subsection{Main risk factors affecting the supply chain}

Taking into account the operating mechanism of the supply chain, its essential characteristics, and the results of previous research bu scholars in supply chain risks (see Table 1), this paper presents a fishbone diagram [27] of supply chain risk factors (shown in Fig. 2).

The main risk factors of the supply chain are:

1. Organization management: The supply chain is a network composed of many upstream and downstream enterprises. Management efficiency and quality of the supply chain have a direct influence on the everyday operations of each enterprise.

2. IT technology: This can be divided into internal and external IT risks. Depending on the situation, each of these can be further divided into software and hardware risks. In addition, the degree of information sharing will also bring about risks, mainly caused by the bullwhip effect of the supply chain, and by artificial exaggeration and manipulation in the information transfer process. 
Table 1: Sources of supply chain risks: a literature review.

\begin{tabular}{|c|c|c|}
\hline Reference no. & Year & Risk factors \\
\hline [18] & 2004 & $\begin{array}{l}\text { Financial condition, complexity and uncertainty within supply chain, } \\
\text { unexpected and unpredictable disruptions, wrong or ineffective } \\
\text { decisions, market }\end{array}$ \\
\hline [19] & 2004 & Process, controls, demand, supply, environment \\
\hline [20] & 2005 & $\begin{array}{l}\text { Problems of coordinating supply and demand, disruptions to normal } \\
\text { activities (operational contingencies, natural hazards, terrorism, } \\
\text { and political instability) }\end{array}$ \\
\hline [21] & 2006 & $\begin{array}{l}\text { Transport, manufacturing, warehousing, procurement, upstream and } \\
\text { downstream relations }\end{array}$ \\
\hline [22] & 2006 & $\begin{array}{l}\text { Operational risks (uncertain customers, demand, uncertain supply, } \\
\text { uncertain cost), disruption risks (natural and man-made disasters } \\
\text { or economic crises) }\end{array}$ \\
\hline [23] & 2008 & $\begin{array}{l}\text { Currency fluctuation, transit time variability, changing forecasts, } \\
\text { quality, safety, business disruption, survival, inventory (and } \\
\text { tools) ownership, culture, dependency and opportunism, oil price } \\
\text { fluctuation, disruptive events affecting suppliers and customers }\end{array}$ \\
\hline [24] & 2009 & $\begin{array}{l}\text { Environment, industry, organizational risk, problem-specific risk, } \\
\text { decision-maker }\end{array}$ \\
\hline [25] & 2010 & $\begin{array}{l}\text { Global sourcing, diverse supplier base, volatile market, product } \\
\text { complexity }\end{array}$ \\
\hline [26] & 2011 & Complexity of supply chains, demand and supply of resources \\
\hline [8] & 2012 & $\begin{array}{l}\text { Organizational risks (inventory risk, process/operational risk, quality } \\
\text { risk, management risk), network risks (supply risk, supplier } \\
\text { default, demand risk), environmental risks (arising from weather, } \\
\text { earthquakes, political, regulatory, market forces, etc.). }\end{array}$ \\
\hline
\end{tabular}

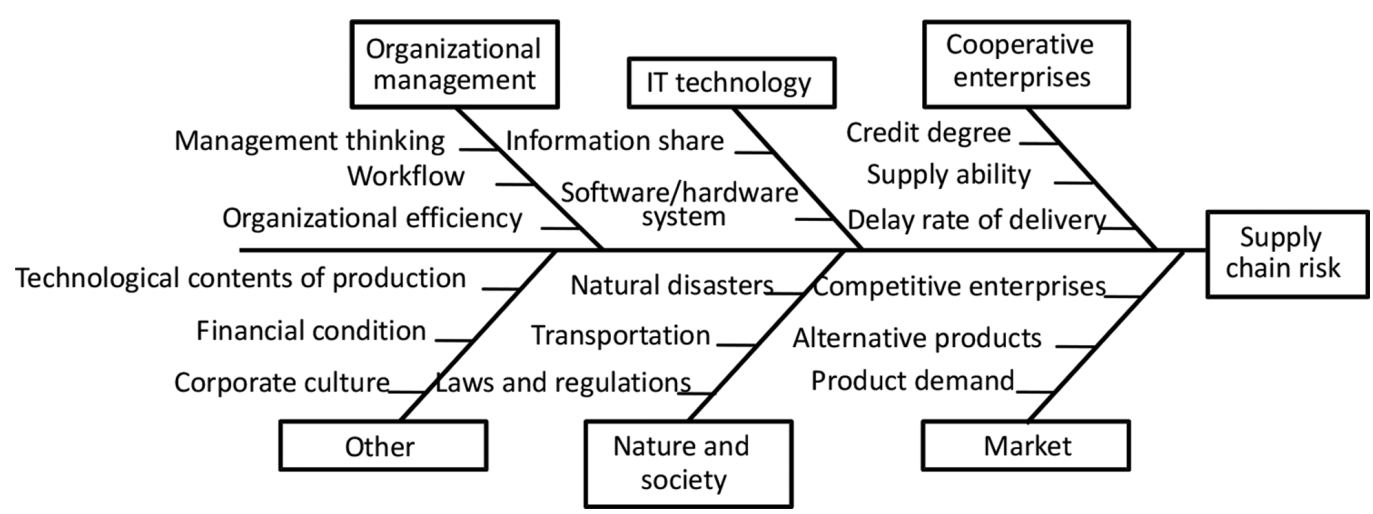

Figure 2: The fishbone diagram of main risk factors in the supply chain. 
3. Cooperative enterprises: Effective supply chains must have good cooperation of enterprises at their foundation. The credit degree, production capacity, supply ability, development ability, and the management level of the cooperative enterprise have a direct impact on the operation and development of the supply chain.

4. Market: Product demand analysis is one of the most important prerequisites for setting up a supply chain. Its results directly decide both how the supply chain is set up and its practical outcome. Not performing a product demand analysis or relying on a faulty one are some of the most important factors in supply chain failure. In addition, the supply chain, similar to any other aspect of enterprise organization, is faced with threats from competitors and alternative products. These two aspects are the main market risks for the supply chain.

5. Nature and society: Natural factors such as earthquake, fire, storm, and heavy snow are risks for the supply chain. These risk factors mainly influence production, supply, and sales in one or several enterprises in a given geographical region. Social risks for the supply chain stem mainly from changes in the social environment, changes in political stability, changes to relevant laws, the development and fluctuation of the economy, and transportation conditions.

6. Other: In addition to the above, other risks include the enterprise culture, its financial status, the technology content of production, and profit distribution. An enterprise culture encompasses the external interactions of the enterprise. A good enterprise culture affects the supply chain positively, but a bad enterprise culture has a negative influence, not only on the enterprise's spirit, but also on society and the cooperation enterprise. The technology content of a product is key to an enterprise's survival and development. A high technical content makes the company dominant and secures its leadership position among the competition, and inversely. For the supply chain, products with a high technical content will consolidate the status of a core enterprise and determine routine operation of the supply chain. Financial conditions of the overall supply chain, on the one hand, influence the financial condition of each enterprise in the supply chain; on the other hand, they refer to the cost of the establishment and maintenance of the normal operation of the supply chain. In large part, the operation costs of the supply chain determine whether or not it should be adopted. In the operation process, some enterprises may take up a lot of capital from upstream and downstream firms. If the financial condition is not stable, the whole supply chain might face a fatal blow at any time. As for profit distribution, the supply chain will eventually collapse, if there is no reasonable profit distribution system between the enterprises in the supply chain.

\section{RISK EVALUATION INDEX SYSTEM}

Based on the main risk factors and the essential characteristics for the supply chain, this paper puts forward the risk evaluation index for the supply chain as shown in Table 2.

\section{CASE STUDY}

A Chinese manufacturer wants to produce one of the two products that have good market potential. After conducting market research and assessing processing capacity, production technology, competition, and other factors, the manufacturer decides to adopt the supply chain operation mode. After a preliminary round of selection, there are two cooperative enterprises left for each product for further evaluation. That means, four schemes exist: scheme I to scheme IV. The manufacturer will want to choose the scheme with the least amount of risk. 
Table 2: Risk evaluation index for the supply chain.

\begin{tabular}{|c|c|c|}
\hline No. & Index & Index description \\
\hline 1 & $\begin{array}{l}\text { Technical content of } \\
\text { product }\end{array}$ & The technical competence of the supply chain for the product \\
\hline 2 & $\begin{array}{l}\text { Credit of cooperative } \\
\text { enterprise }\end{array}$ & $\begin{array}{l}\text { The cooperative enterprise's reputation and integrity, which can be } \\
\text { measured by delivery delay rate, historical credit records, etc. }\end{array}$ \\
\hline 3 & $\begin{array}{l}\text { Supply ability } \\
\text { of cooperative } \\
\text { enterprise }\end{array}$ & The production capacity of the cooperative enterprise \\
\hline 4 & $\begin{array}{l}\text { Information sharing } \\
\text { level }\end{array}$ & $\begin{array}{l}\text { The information communication capability between enterprises } \\
\text { in the supply chain that, from another perspective, also } \\
\text { embodies the degree of bullwhip effect between enterprises }\end{array}$ \\
\hline 5 & $\begin{array}{l}\text { Support from hardware/ } \\
\text { software system }\end{array}$ & The information technology application level in the supply chain \\
\hline 6 & $\begin{array}{l}\text { Threats from } \\
\text { competitive } \\
\text { enterprises }\end{array}$ & The level of competition between enterprises \\
\hline 7 & $\begin{array}{l}\text { Competition from } \\
\text { similar and } \\
\text { alternative products }\end{array}$ & $\begin{array}{l}\text { The quality, cost, popularity, etc. of the product itself; it can } \\
\text { be measured by the market share degree of the product, the } \\
\text { alternative products' condition, and the substitution degree }\end{array}$ \\
\hline 8 & Laws and regulations & $\begin{array}{l}\text { The support for, or the limits placed on, the products by laws and } \\
\text { regulations }\end{array}$ \\
\hline 9 & $\begin{array}{l}\text { Organizational } \\
\text { efficiency }\end{array}$ & $\begin{array}{l}\text { The level of efficiency in the organization and management of } \\
\text { the entire supply chain }\end{array}$ \\
\hline 10 & Financial situation & $\begin{array}{l}\text { The cost of enterprise management, the turnover time of funds, } \\
\text { and the financial position of the company in the supply chain }\end{array}$ \\
\hline 11 & $\begin{array}{l}\text { Satisfaction of the } \\
\text { distribution of profits }\end{array}$ & $\begin{array}{l}\text { The satisfaction degree of all the enterprises with the current } \\
\text { distribution scheme for profits }\end{array}$ \\
\hline
\end{tabular}

In a first step, three expert SCM professionals are invited to assign risk evaluation quality ratings to each scheme. The weight of each risk index is found using the Analytic Hierarchy Process (AHP) $[14,28]$. The two products are denoted as 1 and 2, and the cooperative enterprises are denoted by A, $\mathrm{B}, \mathrm{C}$, and D. The schemes and details of each index's ratings are shown in Table 3.

To use the F-TOPSIS method to sort the schemes, it is necessary to quantify the qualitative ratings in Table 3 by using trapezoidal fuzzy numbers, with $\operatorname{bad}(0.1,0.2,0.2,0.3)$, ordinary $(0.3,0.4,0.4,0.5)$, good or high $(0.5,0.6,0.7,0.9)$, and better or higher $(0.9,0.95,0.95,1.0)$. The trapezoidal fuzzy numbers are just the reverse when quantizing the index for 'threats from competitive enterprises' and 'competition of similar products and alternative products.' The quantified contents of Table 2 become decision matrix $D$ : 
Table 3: Evaluation index ratings of the manufacturer's four schemes.

\begin{tabular}{|c|c|c|c|c|c|}
\hline & & Scheme I & Scheme II & Scheme III & Scheme IV \\
\hline & & Product 1 & Product 1 & Product 2 & Product 2 \\
\hline Risk index & Weight & Enterprise A & Enterprise B & Enterprise $\mathrm{C}$ & Enterprise D \\
\hline $\begin{array}{l}\text { Technical content of } \\
\text { production }\end{array}$ & 0.0524 & Higher & Higher & High & High \\
\hline $\begin{array}{l}\text { Credit of cooperative } \\
\text { enterprise }\end{array}$ & 0.3250 & Better & Good & Better & Ordinary \\
\hline $\begin{array}{l}\text { Supply ability of } \\
\text { cooperative enterprise }\end{array}$ & 0.0385 & Good & Better & Good & Better \\
\hline Information sharing level & 0.1675 & Ordinary & Ordinary & Good & Ordinary \\
\hline $\begin{array}{l}\text { Support from hardware/ } \\
\text { software system }\end{array}$ & 0.0318 & Good & Ordinary & Ordinary & Bad \\
\hline $\begin{array}{l}\text { Threats from competitive } \\
\text { enterprises }\end{array}$ & 0.0575 & Higher & Higher & High & High \\
\hline $\begin{array}{l}\text { Competition from similar } \\
\text { and alternative products }\end{array}$ & 0.1092 & Ordinary & Ordinary & High & High \\
\hline Laws and regulations & 0.0332 & Better & Better & Good & Good \\
\hline Organizational efficiency & 0.0838 & Good & Good & Better & Ordinary \\
\hline Financial situation & 0.0360 & Better & Good & Ordinary & Better \\
\hline $\begin{array}{l}\text { Satisfaction with the } \\
\text { distribution of profits }\end{array}$ & 0.0652 & Good & Good & Better & Better \\
\hline
\end{tabular}

$$
\mathrm{D}=\left[\begin{array}{cccc}
(0.9,0.95,0.95,1.0) & (0.9,0.95,0.95,1.0) & (0.5,0.6,0.7,0.9) & (0.5,0.6,0.7,0.9) \\
(0.9,0.95,0.95,1.0) & (0.5,0.6,0.7,0.9) & (0.9,0.95,0.95,1.0) & (0.3,0.4,0.4,0.5) \\
(0.5,0.6,0.7,0.9) & (0.9,0.95,0.95,1.0) & (0.5,0.6,0.7,0.9) & (0.9,0.95,0.95,1.0) \\
(0.3,0.4,0.4,0.5) & (0.3,0.4,0.4,0.5) & (0.5,0.6,0.7,0.9) & (0.3,0.4,0.4,0.5) \\
(0.5,0.6,0.7,0.9) & (0.3,0.4,0.4,0.5) & (0.3,0.4,0.4,0.5) & (0.1,0.2,0.2,0.3) \\
(0.1,0.2,0.2,0.3) & (0.1,0.2,0.2,0.3) & (0.3,0.4,0.4,0.5) & (0.3,0.4,0.4,0.5) \\
(0.5,0.6,0.7,0.9) & (0.5,0.6,0.7,0.9) & (0.3,0.4,0.4,0.5) & (0.3,0.4,0.4,0.5) \\
(0.9,0.95,0.95,1.0) & (0.9,0.95,0.95,1.0) & (0.5,0.6,0.7,0.9) & (0.5,0.6,0.7,0.9) \\
(0.5,0.6,0.7,0.9) & (0.5,0.6,0.7,0.9) & (0.9,0.95,0.95,1.0) & (0.3,0.4,0.4,0.5) \\
(0.9,0.95,0.95,1.0) & (0.5,0.6,0.7,0.9) & (0.3,0.4,0.4,0.5) & (0.9,0.95,0.95,1.0) \\
(0.5,0.6,0.7,0.9) & (0.5,0.6,0.7,0.9) & (0.9,0.95,0.95,1.0) & (0.9,0.95,0.95,1.0)
\end{array}\right]
$$

For trapezoidal fuzzy numbers, eqn (5) is used for defuzzification [14]:

$$
M=\frac{\left(-a^{2}-b^{2}+c^{2}+d^{2}-a b+c d\right)}{3 \times(-a-b+c+d)}
$$

In eqn (5), $a, b, c$, and $d$ are four numerical trapezoidal fuzzy numbers. 
After defuzzification of matrix $D$, the matrix $D^{\prime}$ is obtained, and after weighting matrix $D^{\prime}$ with the weights shown in Table 3, matrix $V$ is obtained:

$$
D^{\prime}=\left[\begin{array}{llll}
0.95 & 0.95 & 0.68 & 0.68 \\
0.95 & 0.68 & 0.95 & 0.40 \\
0.68 & 0.95 & 0.68 & 0.95 \\
0.40 & 0.40 & 0.68 & 0.40 \\
0.68 & 0.40 & 0.40 & 0.20 \\
0.20 & 0.20 & 0.20 & 0.20 \\
0.68 & 0.68 & 0.40 & 0.40 \\
0.95 & 0.95 & 0.68 & 0.68 \\
0.68 & 0.68 & 0.95 & 0.40 \\
0.95 & 0.68 & 0.40 & 0.95 \\
0.68 & 0.68 & 0.95 & 0.95
\end{array}\right] \quad V=\left[\begin{array}{llll}
0.0498 & 0.0498 & 0.0356 & 0.0356 \\
0.3088 & 0.2210 & 0.3088 & 0.1300 \\
0.0262 & 0.0366 & 0.0262 & 0.0366 \\
0.0670 & 0.0670 & 0.1139 & 0.0670 \\
0.0216 & 0.0127 & 0.0127 & 0.0064 \\
0.0115 & 0.0115 & 0.0230 & 0.0230 \\
0.0743 & 0.0743 & 0.0437 & 0.0437 \\
0.0315 & 0.0315 & 0.0226 & 0.0226 \\
0.0570 & 0.0570 & 0.0796 & 0.0335 \\
0.0342 & 0.0245 & 0.0144 & 0.0342 \\
0.0443 & 0.0443 & 0.0619 & 0.0619
\end{array}\right]
$$

The ideal solution $v^{*}$ and the negative ideal solution $v^{0}$ are calculated with the TOPSIS method:

$$
\begin{aligned}
& v^{*}=[0.0498,0.3088,0.0366,0.1139,0.0216,0.0230,0.0743,0.0315,0.0796,0.0342,0.0619] \\
& v^{0}=[0.0356,0.1300,0.0262,0.0670,0.0064,0.0115,0.0437,0.0226,0.0335,0.0144,0.0443]
\end{aligned}
$$

\begin{tabular}{|c|c|c|c|c|c|}
\hline Risk index & Weight & Scheme I & Scheme II & Scheme III & Scheme IV \\
\hline $\begin{array}{l}\text { Technical content of } \\
\text { production }\end{array}$ & 0.0524 & 0.95 & 0.95 & 0.68 & 0.68 \\
\hline $\begin{array}{l}\text { Credit of cooperative } \\
\text { enterprise }\end{array}$ & 0.3250 & 0.95 & 0.68 & 0.95 & 0.40 \\
\hline $\begin{array}{l}\text { Supply ability of } \\
\text { cooperative enterprise }\end{array}$ & 0.0385 & 0.68 & 0.95 & 0.68 & 0.95 \\
\hline Information sharing level & 0.1675 & 0.40 & 0.40 & 0.68 & 0.40 \\
\hline $\begin{array}{l}\text { Support from hardware/ } \\
\text { software system }\end{array}$ & 0.0318 & 0.68 & 0.40 & 0.40 & 0.20 \\
\hline $\begin{array}{l}\text { Threats from competitive } \\
\text { enterprises }\end{array}$ & 0.0575 & 0.20 & 0.20 & 0.20 & 0.20 \\
\hline $\begin{array}{l}\text { Competition from similar } \\
\text { and alternative products }\end{array}$ & 0.1092 & 0.68 & 0.68 & 0.40 & 0.40 \\
\hline Laws and regulations & 0.0332 & 0.95 & 0.95 & 0.68 & 0.68 \\
\hline Organizational efficiency & 0.0838 & 0.68 & 0.68 & 0.95 & 0.40 \\
\hline Financial situation & 0.0360 & 0.95 & 0.68 & 0.40 & 0.95 \\
\hline $\begin{array}{l}\text { Satisfaction with the } \\
\text { distribution of profits }\end{array}$ & 0.0652 & 0.68 & 0.68 & 0.95 & 0.95 \\
\hline Score for each scheme & & 0.72615 & 0.630171 & 0.730888 & 0.482983 \\
\hline Rank of schemes & & 2 & 3 & 1 & 4 \\
\hline
\end{tabular}

Table 4: Results of scheme selection with F-AHP. 
Using eqns (2) and (3), the Euclidean distance of the ideal solution $v^{*}$ and the negative ideal solution of each scheme is calculated: $\mathrm{S}_{\mathrm{i}}^{*}$ and $\mathrm{S}_{\mathrm{i}}^{0}$

$$
\begin{aligned}
& S_{1}^{*}=0.0571 ; S_{2}^{*}=0.1050 ; S_{3}^{*}=0.0424 ; S_{4}^{*}=0.1943 \\
& S_{1}^{0}=0.1862 ; S_{2}^{0}=0.1024 ; S_{3}^{0}=0.1919 ; S_{4}^{0}=0.0358
\end{aligned}
$$

Finally, each relative index $\mathrm{S}_{i}$ of the distance between each scheme and the ideal solution is calculated on the basis of the equation: $\mathrm{S}_{i}=S_{i}^{0} /\left(S_{i}^{0}+S_{i}^{*}\right)$

$$
S_{1}=0.7653 ; S_{2}=0.4937 ; S_{3}=0.8190 ; S_{4}=0.1555 \text {. }
$$

So, it can be seen that $S_{3}>S_{1}>S_{2}>S_{4}$. As the third scheme's score is highest, it means that its risk is lowest, and that it is the best scheme.

\section{COMPARING RESULTS WITH F-AHP}

To check the results with other techniques, F-AHP was adopted, referred to in Tesfamariam and Sadiq [28], to solve the above case. Table 4 shows the results of scheme selection according to the data in Table 3 using the F-AHP method.

Table 4 shows scheme III as the best scheme and scheme IV as the worst. The selection result using F-AHP is the same as that using F-TOPSIS, which illustrates the validity of F-TOPSIS.

Compared with F-AHP, F-TOPSIS has the following advantages and disadvantages:

1. Both F-TOPSIS and F-AHP can perform quantitative analysis of qualitative problems.

2. By applying F-TOPSIS, the Euclidean distance between the schemes and the ideal solution and negative ideal solution can be obtained, and the difference of the results between schemes is greater by using F-TOPSIS than F-AHP, so F-TOPSIS can distinguish smaller differences between two very similar schemes.

3. The disadvantage of F-TOPSIS is that it is more complicated than F-AHP. However, a lot of software has been developed to easily solve F-TOPSIS, such as Topsis Solver 2013 by Informer Technologies Inc. [29].

4. Other differences between F-AHP and F-TOPSIS are referred to in Ertuğrul and Karakaşoğlu [14].

\section{CONCLUSION}

Supply chain risks have great influence on the operation of the supply chain. Therefore, the correct evaluation of supply chain risks is the key to successful implementation of a supply chain mode of operation. By analyzing the operation mechanism and essential characteristics of the supply chain, and by reviewing the latest literature, this paper presents a fishbone diagram of supply chain risk factors. In the next step, a supply chain risk evaluation index system is set up, taking into account the technical content of the product, credit of the cooperation enterprises, supply ability of the cooperative enterprises, information sharing level, support from the software/hardware system, threats from competitive enterprises, competition from similar and alternative products, laws and regulations, organizational efficiency, financial situation, and satisfaction with the distribution of profits. Finally, this paper proposes the F-TOPSIS-based risk evaluation method and demonstrates the application of this method with a case study. It was found that this method has a good applicability for supply chain risk evaluation. 


\section{ACKNOWLEDGMENTS}

The research was supported by the National Natural Science Foundation of China under grants No. 71071043 and No. 51378160, and the Scientific Research Foundation for Returned Overseas Chinese Scholars of the Harbin Science and Technology Bureau of China under Grant No. JJ20120070.

\section{REFERENCES}

[1] Lambert, D.M., Supply Chain Management: Processes, Partnerships, Performance, The Hartley Press: Jacksonville, USA, 2008.

[2] Min, H. \& Zhou, G., Supply chain modeling: past, present and future. Computer \& Industrial Engineering, 43, pp. 231-249, 2002. doi: http://dx.doi.org/10.1016/s0360-8352(02)00066-9

[3] Cao, K. \& Lin, J., Price decision analysis of closed-loop supply chain under third-party recyclers' competition. International Journal of Advancements in Computing Technology, 21(4), pp. 632-641, 2012. doi: http://dx.doi.org/10.4156/ijact.vol4.issue21.75

[4] Askarany, D., Yazdifar, H. \& Askary, S., Supply chain management, activity-based costing and organizational factors. International Journal of Production Economics, 127, pp. 238-248, 2010. doi: http://dx.doi.org/10.2139/ssrn.1370783

[5] Lockamy III, A. \& Smith, W.I., Target costing for supply chain management: criteria and selection. Industrial Management \& Data Systems, 100(5), pp. 210-218, 2000. doi: http://dx.doi. org/10.1108/02635570010304789

[6] Mukherjee, A., The Spider's Strategy: Creating Networks to Avert Crisis, Create Change, and Really Get Ahead, Financial Times Prentice Hall: USA, 2008.

[7] Brennan, P., Lessons learned from the Japan earthquake. Disaster Recovery Journal, 24, pp. 22-26, 2011.

[8] Ghadge, A., Dani, S. \& Kalawsky, R., Supply chain risk management: present and future scope. International Journal of Logistics Management, 23(3), pp. 313-339, 2012. doi: http:// dx.doi.org/10.1108/09574091211289200

[9] Colicchia, C. \& Strozzi, F., Supply chain risk management: a new methodology for a systematic literature review. Supply Chain Management: An International Journal, 17(4), pp. 403-418, 2012. doi: http://dx.doi.org/10.1108/13598541211246558

[10] Hallikas, J., Virolainen, V.-M. \& Tuominen, M., Risk analysis and assessment in network environments: a dyadic case study. International Journal of Production Economics, 78, pp. 45-55, 2002. doi: http://dx.doi.org/10.1016/s0925-5273(01)00098-6

[11] Jüttner, U., Supply chain risk management: understanding the business requirements from a practitioner perspective. International Journal of Logistics Management, 16(1), pp. 120-141, 2005.

[12] Modarres, M. \& Sadi-nezhad, S., Fuzzy simple additive weighting method by preference ratio. Intelligent Automation and Soft Computing, 11(4), pp. 235-244, 2005. doi: http://dx.doi.org/ 10.1080/10642907.2005.10642907

[13] Wang, Y.-M. \& Elhag, T.M.S., Fuzzy TOPSIS method based on alpha level sets with an application to bridge risk assessment. Expert Systems with Applications, 31(2), pp. 309-319, 2006. doi: http://dx.doi.org/10.1016/j.eswa.2005.09.040

[14] Ertuğrul, İ. \& Karakaşoğlu, N., Comparison of fuzzy AHP and fuzzy TOPSIS methods for facility location selection. International Journal of Advanced Manufacturing Technology, 39(7-8), pp. 783-795, 2008. doi: http://dx.doi.org/10.1007/s00170-007-1249-8 
[15] Harland, C.M., Supply chain management: relationships, chains and networks. British Journal of Management, 7, pp. 63-80, 1996. doi: http://dx.doi.org/10.1111/j.1467-8551.1996. tb00148.x

[16] García-Dastugue, S.J. \& Lambert, D.M., Internet-enabled coordination in the supply chain. Industrial Marketing Management, 32, pp. 251-263, 2003. doi: http://dx.doi.org/10.1016/s00198501(02)00269-9

[17] Bhattacharya, R. \& Bandyopadhyay, S., A review of the causes of bullwhip effect in a supply chain. International Journal Advanced Manufacturing Technology, 54, pp. 1245-1261, 2011. doi: http://dx.doi.org/10.1007/s00170-010-2987-6

[18] Christopher, M. \& Lee, H., Mitigating supply chain risk through improved confidence. International Journal of Physical Distribution \& Logistics Management, 34(5), pp. 388-396, 2004. doi: http://dx.doi.org/10.1108/09600030410545436

[19] Christopher, M. \& Peck, H., Building the resilient supply chain. International Journal of Logistics Management, 15(2), pp. 1-14, 2004. doi: http://dx.doi.org/10.1108/09574090410700275

[20] Kleindorfer, P.R. \& Saad, G.H., Managing disruption risks in supply chains. Production and Operations Management, 14(1), pp.53-68, 2005. doi: http://dx.doi.org/10.1111/j.1937-5956.2005. tb00009.x

[21] Gaudenzi, B. \& Borghesi, A., Managing risks in the supply chain using the AHP method. International Journal of Logistics Management, 17(1), pp. 114-136, 2006. doi: http://dx.doi. org/10.1108/09574090610663464

[22] Tang, C.S., Perspectives in supply chain risk management. International Journal of Production Economics, 103(2), pp. 451-88, 2006.

[23] Manuj, I. \& Mentzer, J., Global supply chain risk management strategies. International Journal of Physical Distribution \& Logistics Management, 38(3), pp. 192-223, 2008. doi: http:// dx.doi.org/10.1108/09600030810866986

[24] Rao, S. \& Goldsby, T., Supply chain risks: a review and typology. International Journal of Logistics Management, 20(1), pp. 97-123, 2009. doi: http://dx.doi.org/10.1108/09574090910954864

[25] Ghadge, A., Dani, S. \& Kalawsky, R.A., Framework for managing risks in the aerospace supply chain using systems thinking. Proc. of the 5th Int. Conf on System of Systems Engineering, IEEE, pp. 22-24, 2010.

[26] Giannakis, M. \& Louis, M., A multi-agent based framework for supply chain risk management. Journal of Purchasing \& Supply Management, 17, pp. 23-31, 2011. doi: http://dx.doi. org/10.1016/j.pursup.2010.05.001

[27] Wikipedia, available at http://en.wikipedia.org/wiki/Ishikawa_diagram

[28] Tesfamariam, S. \& Sadiq, R., Risk-based environmental decision-making using fuzzy analytic hierarchy process (F-AHP). Stochastic Environmental Research and Risk Assessment, 21(1), pp. 35-50, 2006. doi: http://dx.doi.org/10.1007/s00477-006-0042-9

[29] Informer Technologies, Inc., available at http://softadvice.informer.com/Download_Fuzzy_ Topsis_Software.html 